bibliographical research on one's own account. As the reprints are meant to reach those who do not see the journal, it seems indeed thoughtless to give on them a citation which cannot be completed except by reference to a file of the journal. The same applies to (4). In (5), which is due to excess of zeal, the author's name if it appears at all is coyly hidden between those of the editor and publisher (as in the case of the railway station which was called Bovril). This at the best is distracting to the eye; at the worst, in the hands of an assistant who is not very strong in foreign languages, it can lead to quite remarkable results in the filing.

Thirdly, on the more general question of bibliography, apart from the immediate one of separates, journals have various idiosyncrasies. There are for example some which begin over again at p. 1 for each part within the volume, or have separately pag. inated appendices. Surely the volume should always be the unit. There is one venerable and dis. tinguished London journal sent out in continuously numbered parts; the volumes are made up of an irregular number of these parts, but there is nothing on the cover to show which part begins or ends a volume. Then there are a great many journals which still use roman numerals, a quaint but eye-straining practice. There is the confusing trick of numbering the plates, including their versos which are always blank, along with the text; and finally there is the practice of putting last year's date on an overdue part. Such falsification of a document is scarcely an example of scientific integrity.

To conclude, it is evident that many journals which are scientific in content are traditional in form. It may be that there are certain advantages, of which I am unaware, in the practices which I deprecate, but it seems more likely that they have persisted, not on account of any essential virtue, but simply because it has been no one's business to have them altered. The eminent men of science who conduct the journals may consider such small matters unworthy of their attention; but convenience and consistency underlie all scientific method and might well be applied in this case as in others.

\section{BRENHILDA SCHAFER} (Librarian).

John Innes Horticultural Institution, London, S.W.19. Jan. 1.

\section{Graphical Determination of Contemporaries}

THE illustration which Mr. Lucas gives of his graphical determination of contemporaries ${ }^{\mathbf{1}}$ is perhaps an unfortunate one, for even with the help of this example his letter affords no clue as to what he is trying to do or why he has chosen an oblique method of doing it.

The duration of a life is very simply represented by the length of a line or, better still perhaps, by the interval between two points and it would seem that the interesting chronologies ${ }^{2}$ of Prof. Thomas Young are admirably adapted to the determination of contemporaries.

In referring to the Chronology of Mathematicians and Mechanics, reproduced in Fig. I, I was interested to read, on the facing page, Young's counsel of perfection to everyone who is desirous of enlarging the sphere of our knowledge with respect to any

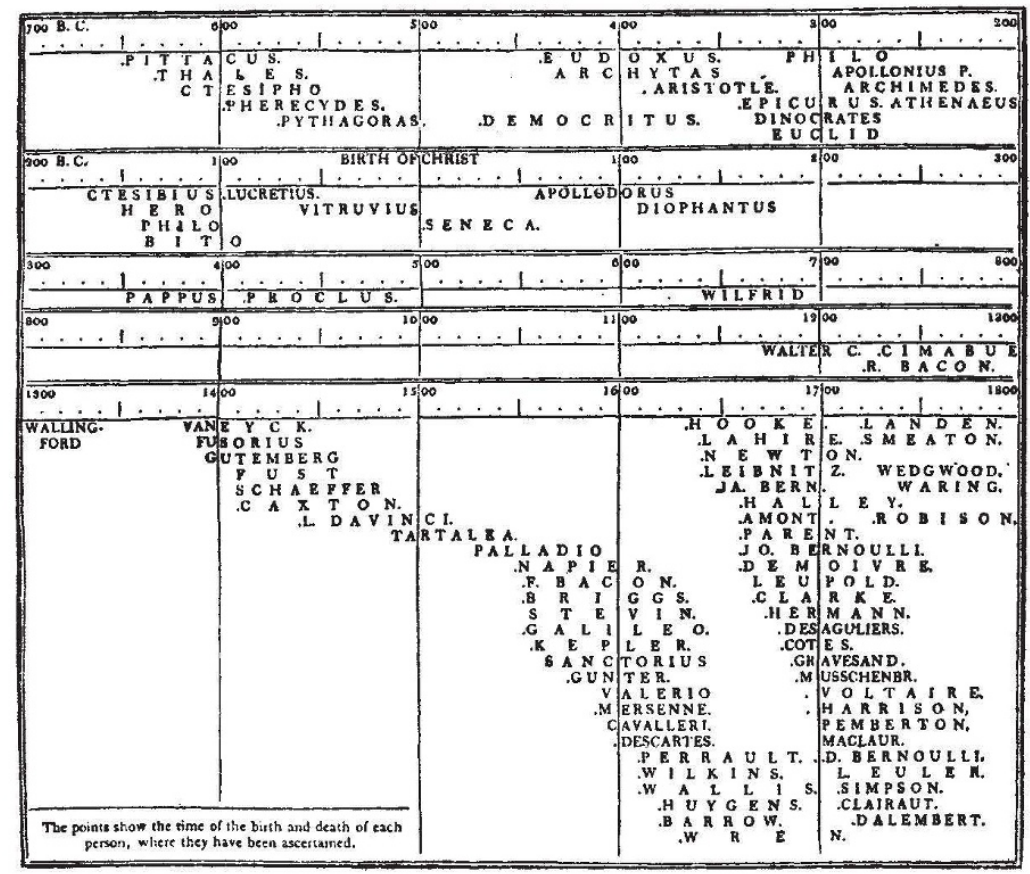

FIt. 1.

branch of science : "to collect that previous knowledge of all that has been already done with the same view, which, in justice to himself, he ought to acquire before he enters on the pursuit, or at any rate, in justice to the public, before he calls on the world at large to participate in his improvements and discoveries".

Greenbank, Garston,

A. F. Dufton.

Hertfordshire.

Jan. 30 .

1 NATURE, 133, 141, Jan. 27, 1934

2 Young, T., "A Course of Lectures on Natural Philosophy and the Mechanical Arts", London, 1807.

\section{The Viability of Spirochætes dried in Vacuo}

Ix is well known that all kinds of spirochrtes, both pathogenic and non-pathogenic, are unable to withstand ordinary desiccation, for repeated experiments have shown that they very soon lose their vitality after ordinary drying. Hitherto, however, no attempts seem to have been recorded on the results of drying these organisms by the special methods used with success for the preservation of certain filterable viruses and some bacteria. In view of the difficulty and expense of maintaining strains of spirochætes in the laboratory, it seemed of interest to see whether they could be preserved in the same way, and the results show that under special 